INTERNATIONAL JOURNAL OF MULTidisciplinARY RESEARCH AND ANALYSis

ISSN(print): 2643-9840, ISSN(online): 2643-9875

Volume 04 Issue 11 November 2021

DOI: 10.47191/ijmra/v4-i11-29, Impact Factor: 6.072

Page No.- 1675-1677

\title{
Covid-19 and Diabetes Mellitus a Serious Concern for the Covid - 19 Patients: A Brief Review
}

\section{Ajaz Ahmed wani}

Head Dept.of Zoology Govt.Degree College Doda ,Jammu and Kashmir-182202

\begin{abstract}
Diabetes mellitus a group of metabolic disorders in which a person has high blood sugar, either because the pancrease does not produce enough insulin or because cells do not respond properly to the insulin that is produced. Coronavirus disease (Covid -19) recently emerged with formidable infectivity and high mortality. Emerging data suggest that diabetes is one of the most prevalent comorbidities in patients with covid -19, although casual relationship has not been investigated, where as pre existing diabetes can be considered as a risk factor for the adverse outcome of covid -19.The present article discussed the literature related to the corelation between diabetes and covid -19 .
\end{abstract}

KEY WORDS: Diabetes mellitus,Covid-19, Comorbidities, Coronavirus.

\section{INTRODUCTION}

Diabetes mellitus is a group of metabolic disorders characterised by a high blood sugar level over a prolonged period of time [1]. In common man's laungage it is called sugar. This increase in blood sugar is due to either the pancrease not producing enough insulin or the cells of the body not responding to the insulin produced [2].There are three main types of diabetes mellitus:

1. Type 1 diabetes :- This type of diabetes result from failure of the pancrease to produce enough insulin due to loss of beta cells [3]. The loss of beta cells is caused by an autoimmune response [4], where as cause of this autoimmune response is unknown.

2. Type 2 diabetes:- This form of diabetes begins with insulin resistance, a condition in which cells fails to respond to insulin properly [3].As the disease progress a lack of insulin may also develop.This type was previously referred to as insulin - dependent diabetes mellitus (IDDM) or " adult dependent diabetes"[3]. The most important cause is a combination of excessive body weight and insufficient exercise[3].

3. Gestational diabetes:-It is third main type and occurs when pregnant women without a previous history of diabetes develop high blood sugar level.

Diabetes type 1 is managed with insulin injection, where as treatment and prevention of type 2 diabetes involves maintaining a healthy diet, regular physical exercise, normal body weight and avoid use of tobacco. It is treated with medication such as insulin sanitizers with or without insulin [5]. Control of blood pressure and maintaining proper food and eye care are important for people with the disease[3]. Gestational diabetes usually resolves after the birth of baby [6].

According to 2019 estimate 463 million people has diabetes wordwide ( 8.8/ of the adult population) with type 2 diabetes making about 90/ of the cases [7]. Rates are similar in men and women [8].In 2019, 4.2 million deaths occured by diabetes [7]. The diabetes is the 7th leading cause of death globally[9].

\section{SIGNS AND SYMPTOMS}

It includes the frequent urination (Polyuria), increased thrist (polyphagia) and appetite, weight loss. Symptoms may develop rapidly within week or months in type 1 diabetes, where as in type 2 diabetes symptoms develops slowly[10].If left untreated diabetes can causes many health complications and these includes diabetic ketoacidosis, hyperosmular hyperglacemia state or death [11]. The other symptoms include blurred vision, fatigue, headache, slow healing of cuts and itchy skin. Pronlonged high blood glucose can cause glucose absorption in the lenses of eyes, which leads to change in its shape resulting in vision change and long term vision loss can causes diabetic retinopathy. Skin rashes also develops in diabetic patients and are collectively called as diabetic dermadromes[12]. All forms of diabetes increase the risk of long term complications. Such complications develops after many years, but may be the first symptoms in those who have otherwise not received a diagnosis before that time. The major 


\section{Covid-19 and Diabetes Mellitus a Serious Concern for the Covid -19 Patients: A Brief Review}

long term complications relate to demage to blood vessels. It increase the risk of cardiovascular disease [13], and about 75/ of deaths in people with diabetes are due to coronary artery disease.

\section{DIABETES MELLITUS AND COVID -19}

Patients with diabetes mellitus have increased predisposition to viral and bacterial infections including those affecting the respiratory tract [14]. One of the mechanism responsible for this predisposition is the "Lazy leucocyte syndrome" which represents impaired leucocyte function of phagocytosis (impaired immunity). This further emphaisizes the likelihood of increased propensity of SARS-COV-2 infection in diabetetic cohorts[15]. Microangiopathy in diabetes mellitus also impairs the lung compliance with consquent affectation of the exchange of gases. This impairment may result in the proliferation of some respiratory pathogens including SARS-COV-2 [16]. The respiratory changes occurs in diabetic patients that affect lung volumes and pulmonary duffusing capacity. According to Muniyappa and Gubbi summerised the potential mechanism through which diabetes increase the SARSCOV-2 morbidity and mortality

a. Increase cellular binding affinity anf efficient viral entry.

b. Decrease viral clearence

c. Reduce T- cell function

d. Increased susceptibility to hyperinflamation and cytokine storm.

The study carried out in Wuhan city of China on the characterstic of of covid -19 patients showed that patients with diabetes mellitus accounted for 2-20/ of positive cases and also constituted about 7.1/ of ICU admission [17].A similar study was done in New York among 5,700 hospitalised patients with covid -19 showed that 1,808 patients (33.8/) were diabetic ,3026 (56.6) had systematic hypertension, while 1,737 were obese. This study generally emphaisised the impact of non communicable disease on Covid-19 infection [18].

Glycemic variability is a prognostic factor in diabetic patients with covid -19 infection . Hyperglycemia worsens the outcome by the process of cytokine storms, endothelial dysfunction and multiple organ injuries[19]. In the lungs the primary target of covid 19 , hyperglycemia leads to a rapid deterioration in spirometric functions, especially decreased forced respiratory volume in 1 second and forced vital capacity [20]. According to Philips et al that in hyperglycemic states, there is elevated glucose concentration in the respiratory epithelium which may effect its innate immune capacity. This hperglycemic also increases cardiovascular mortality by accentuating monocytes which are pro inflammatory and enhancing the platlet aggregation [21], where as severe hperglycemia which may occur with strict glycemic control may worsen the overall mortality rate.

The presence of diabetes mellitus and individual degree of hyperglycemia seems to be independently associated with Covid -19 severity and increased mortality [22]. Furthermore the presence of typical comlications of diabetes mellitus ( heart failure and chronic kidney disease) increases Covid -19 mortality [23]. Glycaemic deterioration is a typical complication of Covid -19 in patients with impaired glucose regulation or diabetes mellitus .For example in patients requiring insulin SARS-COV infection was associated with a rapidly increasing need for high doses of insulin [24].

\section{CONCLUSION:}

People with diabetes and infected with virus are at greater risk of worse prognosis and mortality .These individuals represent a large vulnerable segment of the covid -19 population. The poorer prognosis of people with diabetes is the likely consequences of the syndromic nature of the disease, hyperglycemia, old age, comorbidities and in oarticular hypertension, obesty and cardiovascular disease all contribute to increase the risk in these individuals. Therefore diabetes management in patients with covid -19 poses a great clinical challenge, one that requires a much integrated team approach as this is an indispensable strategy to reduce the risk of medical complication and death as much as possible. The inter relationship between diabetes and covid -19 should trigger more research to understand the extant to which specific mechanism of the virus might contribute to worsening of glycemic control, and in some cases to the striking development of diabetic ketoacidosis or hperglycaemic hyperosmolar syndrome.

\section{REFERENCES}

1) "About diabetes". World Health Organisation .31 March 2014.

2) Shoback DG, Gardner D, eds. (2011). " Chapter 17". Greenspans basic and clinical endocrinology (9th ed.). New York: McGraw-Hill Medical.ISBN 978-0-07-162243-1.

3) "Diabetes fact sheet N312".WHO.Otober 2013.

4) Norman A, Henry H (2015).Hormones .Elsevier .pp.136-137.ISBN9780123694447.

5) "The top 10 causes of death fact sheet N310" .World Health Organisation .October 2013. 


\section{Covid-19 and Diabetes Mellitus a Serious Concern for the Covid -19 Patients: A Brief Review}

6) Cash ,Jill (2014).Family Practice Guidelines.Springer.P.396.ISBN 978-08261-6875-7.

7) IDF Diabetes Atlas Nith Edition 2019.www. diabetes satlas.org.Retrieved 18 May 2021.

8) Vos T, Flaxman AD,Naghavi M.Lozano R, Michaud C, Ezzati M,et.al (Dec.2012)." Years lived with diability for 1160 sequelae of 289 disease and injuries 1990-2010,a systamatic analysis for the Global Burden of disease study 2010, Lancet,380(9859):2163-96.

9) "What is diabetes "? Centre for Disease Control and Prevention .11 March 2020.

10) "WHO, Diabetes mellitus ", WHO. Retieved 2019-03-23.

11) Kitabchi. AE, Umpierrez GE, Miles JM, Fisher JN.(July2009). Hyperglycemic crisis in adult patients with diabetes". Diabetes care.32(7): 1335-43.

12) Rockefeller,J.D(2005).Diabetes: Symptoms ,Causes, Treatment and Prevention.ISBN 978-1-5146-0305-5.

13) Sarwar N,Gao P,Seshasai SR, Gobin R,Kaptoge S,Di Angelantonio E, Ingelsson E ,Lawlor DA Selvin, E,Stampfer M.Stehonwer $C D$, Lewington et al (June2010). "Diabetes mellitus fasting gloucose concentration and risk of vascular disease : a collaborative meta analysis of 102 prospective studies " Lancet.375(9733):2215-22.

14) Badawi A, Ryoo SG. Prevalence of diabetes in the 2009 influenza (H1N1) and the middle East respiratory syndrome coronavirus : a systamatic review and meta- analysis .Public Health Res.2016;5(3):733-19.

15) Muniyappa R,Gubbi S. Covid -19 pandemic coranavirus and diabetes mellitus .Am J Physio Endocrinal Metab.2020; 318(5): E 736-41.

16) Ardigo D,Valtuena S,Zavasoni I ,Basoni MC, Delsignor R.Pulmonary complication of diabetes mellitus : the role of glycemic control

17) Curr Drug Targets Inflamm Allergy .2004;3(4):455-8.

18) Haung $C$, Wang $Y, L i X$, Ren $L$, Zhao,J, Hu, $Y$, et al.Clinical features of patients infected with 2019 novel coronavirus in Wuhan China.Lancet.2020. 395(10223):497-506.

19) Richardson S, Hirsch JS, Narasimhan Do.Presenting characterstic, comorbidities and outcomes among 5700 patients hospitalised with Covid -19 in the New York City Area. JAMA.2020,: 323(20): 2052-9.

20) Constatino S, Paneni F, Battista R, Castello L, Capretti G, Chiandotto S.Impact of glycemic variability on chromatin remodeling oxidative stress and endothelial dysfunction in patients with type 2 diabetesand with target HbAlc.Diabetes .2017; 66(9):2472-82.

21) El- Azeem IAA, Handy G, Amin M.Rashad A. Pulmonary function changes in diabetic lung .Egypt J Chest .disease .2013; 62(3):513-7.

22) Iqbal A, Prince LR, Nuvodvorshy $P$, Bernyak A, Thomas MR Birch L et al ,Effect of hypoglycemia on low dose endotoximia in humans : J Clin Endocrinol Metab.2019;104(4):1187-19.

23) Grasselli, G.et al. Baseline characterstic and outcomes of 1591 patients infected with SARS Cov-2 admitted to ICUs of the Lombardy region, Italy .JAMA 323, 1574-1581(2020). 